\title{
CD22 Negative
}

National Cancer Institute

\section{Source}

National Cancer Institute. CD22 Negative. NCI Thesaurus. Code C162065.

An indication that CD22 expression has not been detected in a sample. 